\title{
Forging the Remittances-to- Development Nexus
}

\section{Conceptual Linkages and Political Practices}

The previous chapter analyzed the governmental work involved in the construction of remittances as a financial flow. In this chapter I turn to look at the governmental work involved in the portrayal of the nexus between remittances and development and the identification of market-based solutions capable of exploiting that connection. How, exactly, have remittances been framed as a potentially valuable contributor to development in the global South? In the following pages, I examine the contours and content of this aspect of the R-2-D agenda, dissecting the particular understandings of the connection between remittances and development that have animated the work of agencies such as the Multilateral Investment Fund (MIF), the International Fund for Agricultural Development (IFAD), Inter-American Dialogue (IAD), and the World Bank. In particular, I focus on how these institutions have forged the conceptual link between remittances and development and on the specific practices that policy entrepreneurs within these institutions have undertaken in order to make their political project a reality. With this work, 
the purveyors of the R-2-D agenda are involved in a process of "rendering technical" the complex relationship between transnational migration, remittances, and development. Tania Murray $\mathrm{Li}$ suggests that this process of rendering technical is about "extracting from the messiness of the social world, with all the processes that run through it, a set of relations that can be formulated as a diagram in which problem (a) plus intervention (b) will produce (c), a beneficial result" ( $\mathrm{Li}, 2007 \mathrm{a}: 265)$. In our case, the policy designers suggest that the problem of the underutilization of migrants' remittances (a) can be remedied through a series of market-based interventions (b) that promise to result in greater (financial) development (c).

There have been some subtle differences in how each of the major development agencies has portrayed this relationship and the particular set of policy interventions that promise to transform remittances from an unrecognized and underutilized international financial flow into a robust contributor to development in migrant-sending countries and regions. Despite these minor differences, there are common themes that unite these agencies around a vision of how remittances can contribute to development processes in the global South. As we will see, each of these major themes identifies in its own particular way how the incorporation of migrants and their monies into financial institutions and markets constitutes both the means and the ends of development.'

In essence, remittances have been incorporated within an increasingly financialized development discourse and practice along three lines: reducing the cost of remittance-transfer services; promoting the democratization of financial products and services; and linking remittances to "innovative sources of development finance." In the first of these areas, development 
agencies focus on the cost of remittance-transfer services and suggest that these could be reduced through further market competition in the transfer-services industry. This part of the agenda is imagined to contribute to development by reducing costs to remitters and leaving more money in the pockets of migrants and their family members.

The second theme has been to encourage the use of formal financial institutions as a means to bring remitters and the recipients of remittances into the financial mainstream and usher in a new epoch characterized by financial democracy and economic citizenship. Here development would derive from granting migrants and their family members access to financial services, which would help activate their entrepreneurial energies; development would also be propelled by further capitalizing the banking sector in migrant-sending regions, as these financial intermediaries would then efficiently distribute these new monies to capital-hungry firms and entrepreneurs whose activities would create jobs and opportunities and, in the process, help bring an end to outmigration.

The third and final theme has focused on leveraging remittances through innovative financing mechanisms such as remittance-securitization schemes. These innovative financial instruments, according to their promoters, promise to offer government and private-sector entities in remittancesreceiving countries access to financing on more favorable terms in global capital markets. In these discussions it seems that access to global capital markets itself is an indicator of development.

In what follows I examine these three lines of action, emphasizing the concrete governmental work carried out by policy 
experts and entrepreneurs within the development agencies as they attempted to reshape reality to conform to their market-centric discourse.

THE GOVERNMENTAL WORK OF MARKET-BASED

SOLUTIONS: REDUCING TRANSFER COST

Shortly after the MIF remittances program began its work, it released what would become a recurring report, entitled "Sending Money Home" (MIF, 2003). This report-subtitled "An International Comparison of Remittance Markets"documented the costs associated with remittance transfers to the Latin American and Caribbean (LAC) region, demonstrating that these were significantly higher than in any other region of the world. Aggregate costs paid by migrants to send their remittances to the LAC region reached some $\$ 4$ billion in 2002, or a little over 12 percent of the $\$ 32$ billion sent to the region that year. The MIF report noted that this i2-percent cost was around 50 percent higher than the costs associated with sending monies to other "major recipient countries" (MIF, 2003: 6).

Demonstrating concern over these high costs, one of the MIF program's primary objectives since the founding of its project cluster in 200I was to "reduce the cost and facilitate the transmission of remittances" (MIF, 200I: 5). By 2004 this had become one of the program's two principal goals, which were laid out in a "Statement on Remittances" presented during its "Remittances as a Development Tool" regional conference in Lima, Peru, in March of that year. With that statement, the program committed itself to: (I) reducing the cost of remittance transfers to the LAC region by 50 percent within the following five 
years; and (2) increasing to 50 percent the proportion of remittance recipients receiving their monies through formal financial institutions (MIF, 2004: 2).

During the interview I conducted with the former manager of the MIF, Donald Terry, he described to me the different elements of the MIF program's work on remittances over the last decade. We had the following interaction about the goal of cost reduction:

Donald Terry (DT): The second obvious [issue] was to help lower transaction costs. And, you know, we didn't have to do all that much other than to make it clear that there were billions and billions and billions of dollars being sent ...

$M B$ : Because as soon as you did that you ... encouraged competition in the industry ...?

DT: Yeah, competition doesn't always work, but in this case it did. . . It was, "Oh, my God, there's billions of dollars. We should get a piece of that."

(Interview with Donald Terry, April 26, 2009)

Terry is asserting here that there have been significant reductions in the cost of remittance-transfer services in recent years and that these reductions have been the result of market forces; in essence he is arguing that, seeing significant profit-making potential, additional market actors entered the remittances-transfer industry and that the entry of these additional firms led to increased competition and, ultimately, price reductions for consumers. This representation is only a partial accounting of the factors that went into price reductions in recent years. Most important for our purposes, Terry's assertion that the MIF "didn't have to do all that much" to contribute to the reduction in transfer costs conceals the significant work that the program and its allies put into developing a particular understanding of the remittances-transfer industry, its 
limitations, and the options they identified for improving the industry and market conditions.

During an earlier interview with another MIF staffer I was told that the program had engaged in a variety of practices to ensure reductions in transfer fees and costs. This staffer suggested that the MIF program "put a lot of work into" its attempts to lower transfer costs, in large part because of the belief that the leading transfer companies were making unreasonable profits from these services. As he described it, the major transfer companies were charging fees that constituted 25 percent of a transaction. Within the MIF program they found this cost structure to be "outrageous," and they attempted to muddy the reputation of some of the major players in the industry, naming and shaming them for the "frothy profit" they were extracting from migrant remitters (Interview with MIF staffer, 2009).

These MIF program efforts at naming and shaming were among larger moves during the late 1990s and early zooos aimed at tarnishing the reputations and forcing changes in the business practices of the major money-transfer companies. In those years, these nonbank financial-services firms were repeatedly sued over their fee structures and advertising practices. One high-profile lawsuit was a class-action case brought on behalf of Mexican migrant remitters that accused Western Union, Orlandi Valuta, and MoneyGram of engaging in fraudulent practices because their advertisements, which would regularly make claims like "Send $\$ 300$ to Mexico for $\$ 15$, , did not alert their potential customers that the companies would also profit from the exchange-rate spread-the difference in the price the companies paid for Mexican pesos and the exchange rate they offered their customers when converting dollars into pesos for distribution in Mexico. This class-action suit was settled before 
judgment, with the companies offering, among other things, to provide nearly $\$ 400$ million in coupons to their previous customers and committing themselves to inform customers in future advertisements of the existence of the exchange-rate spread. A federal appeals court would later deny a challenge to the adequacy of this settlement and, in the process, offer some valuable ammunition to the transfer-service providers as they defended themselves from the extensive naming-and-shaming campaigns to which they were being subjected. In its decision, the appeals court suggested that the money-transfer business was really no different from any other type of retail activity:

This settlement is more in the nature of a PR gesture, coupled with the goal of freedom from a drumbeat of litigation (similar suits have been filed in many state and federal courts across the nation), than an exchange of money (or coupons) for the release of valuable legal rights. No state or federal law requires either currency exchanges or wire-transfer firms to disclose the interbank rate at which they buy specie, as opposed to the retail rate at which they sell currency (and the retail price is invariably disclosed). That is why plaintiffs have been driven to make generic fraud claims. But since when is failure to disclose the precise difference between wholesale and retail prices for any commodity "fraud"?

Money is just a commodity in an international market. [Citation omitted.] Pesos are for sale-at one price for those who buy in bulk (parcels of $\$ 5$ million or more) and at another, higher price for those who buy at retail and must compensate the middlemen for the expense of holding an inventory, providing retail outlets, keeping records, ensuring the recipient is the one designated by the sender, and so on. Neiman Marcus does not tell customers what it paid for the clothes they buy, nor need an auto dealer reveal rebates and incentives it receives to sell cars. This is true in financial markets no less than markets for physical goods. The customer of a bank's foreign-exchange section (or an airport's currency kiosk) is 
quoted a retail rate, not a wholesale rate, and must turn to the newspapers or the Internet to determine how much the bank has marked up its Swiss Francs or Indian Rupees.

(In the Matter of Mexico Money Transfer Litigation, $267 \mathrm{~F}_{3} \mathrm{~d}$ 743)

This judicial support for the transfer firms' practices of wringing concealed profits from the exchange-rate spread made clear that the strategy of legally challenging the pricing practices of the major players in the remittances industry was unlikely to prosper. This resolution, and the suggestion that money "is just a commodity in an international market," also served to take the bite out of the naming-and-shaming campaigns portraying the industry's practices as unethical and potentially unlawful. The remittances-to-development advocates were forced to accept that legal and reputational challenges to the industry's leading firms would likely not be effective at bringing price reductions.

In subsequent years, the efforts of the MIF program staffers and their allies went well beyond these public attempts to smear the reputation of the large transfer companies. And indeed, as Donald Terry suggested in the quote above, the issue of increased competition would become central to the strategy and ultimate success in efforts to reduce costs. But, contrary to Terry's suggestions, that competition did not spontaneously occur as a result of market forces, with new firms reacting to market signals, entering the profitable industry, and driving down costs to migrant remitters.

The suggestion that recent changes in the remittances industry were solely the result of market forces and competition does, of course, hold real allure. This suggestion encapsulates and further extends a market-fundamentalist ideology that champions "free markets" over "intrusive" government action. The sway of this ideological interpretation was evidenced during a 
2003 hearing in the U.S. House of Representatives' Financial Services Committee, entitled "Remittances: Reducing Cost, Increasing Competition, and Broadening Access to the Market." In his testimony, Texas representative Jeb Hensarling referred to a newspaper account of how banks and credit unions had begun to compete vigorously with the traditional money-transfer companies and, as a result, fees had dropped "from approximately 20 percent to as low as 4 percent in the last decade." These developments suggested to Hensarling that market forces were sufficient to bring transfer prices down to a reasonable level. He thus concluded that "The end product of this increase in competition and innovation is what is most important to consumers, more choices at lower cost. The free market, not the government, has brought about this result" (Hensarling, 2003: 4).

This free-market interpretation suited the MIF program as well, as it ran in line with the agency's overarching mission to finance and promote private-sector development across the LAC region. I intend to illustrate, however, that despite this pro-market and antigovernment rhetoric, the introduction of increased competition and the resultant reduction of transfer fees was not the result of the hidden hand of the market. Instead, these resulted from the concerted and sustained efforts of those within the MIF program and allied organizations in government and civil society whose promotion of the R-2-D agenda brought this competitive environment into being. The governmental work of these actors, whether located within a formal governmental agency or not, worked to shape the contours of the remittance-transfer industry and to govern the conduct of the market entities operating within it. In the following pages I examine three types of governmental work that went into the construction and implementation of this market-based solution 
to the problem of high remittances-transfer costs: (I) creating knowledge about the structure of the industry; (2) elaborating best-practice recommendations for regulators and market entities; and (3) disseminating pricing information to consumers via dedicated Web sites.

\section{CREATING AND CIRCULATING KNOWLEDGE ABOUT}

THE REMITTANCES-TRANSFER INDUSTRY

The MIF program and allied organizations such as the InterAmerican Dialogue and the Pew Hispanic Center have since the early 2000 s funded and/or conducted research into the structure of the money-transfer industry, highlighting the players involved, the transfer technologies in use, and the level and determinants of costs to consumers. This research has also strongly emphasized the importance of banks and credit unions entering the industry and competing with the long-standing money-transfer operators for a share of the market.

The research carried out by Manuel Orozco, director of the Remittances and Development Program at the Inter-American Dialogue, often funded by partner organizations such as the MIF (Orozco, 2002) or the Pew Hispanic Center (Orozco, 2004), is indicative of this work. Orozco had begun conducting research on remittances in the late I99os and, after coming to the attention of the MIF's manager, Donald Terry, he was funded to develop detailed research on the structure of the remittancestransfer market. In the early 200os, Orozco conducted a number of surveys of market entities and released reports (Orozco, $2002,2003,2004)$ that documented the evolution of the market, highlighting the entry of new players, including a small number of banks and credit unions, and the gradual reduction of 
costs to consumers, in terms of both exchange-rate differential and direct fees. While these survey findings indicated that fees rarely reached the "outrageous" 25-percent level that MIF staffers had suggested was the impetus for their cost-reduction work, these surveys showed that the cost to send $\$ 200$ to Latin America in November 200I was $\$ 17.46$, or 8.7 percent (Orozco, 2003: 4), and by February 2004 this had dropped to 7.6 percent (Orozco, 2004: 15). Despite these reductions, Orozco complained that, as an aggregate amount, "These costs represent more than two billion dollars in payments to wire transfer businesses by a consumer population largely composed of low-income immigrants" (Orozco, 2004: I6). This strategy of aggregating the total costs incurred in sending money was a central pillar in the development agencies' argument about the remittances-anddevelopment nexus and a recurring theme in their research reports and policy proposals for lowering transaction costs. An MIF report co-sponsored by the Pew Hispanic Center argued that "Reducing the cost to 5 percent of the amount remitted would free up more than \$ billion next year for some of the poorest households in the United States, Mexico and the Central American countries covered by the Pew Hispanic Center projections. Between now and the end of the decade, the savings could amount to some $\$$ I2 billion. It goes without saying that such a sum could change many, many lives" (Suro et al., 2002: 4). Donald Terry summed up the value of "billions and billions" of aggregate savings that cost reductions could represent by telling me "that is real money, as they say" (Interview with Donald Terry, April 26, 2009).

In identifying how to move toward still lower prices, Orozco and other researchers (Bair, 2003; Suro and Bendixen, 2002) inevitably noted that prices were lowest in markets with the greatest 
number of competing firms. The market for sending remittances from the United States to Mexico was often invoked as the prime example of a highly competitive market that resulted in lower costs to remitters. The following excerpt from one of Orozco's early reports (2002: Io) illustrates how this argument was presented:

The price of sending remittances varies significantly and a key determinant in those prices is the extent of market competition to send remittances to that recipient country.... Mexico is the country with the lowest fees among the nine countries studied. It is also the country with the greatest market choices for customers. The competition in Mexico ranges from small businesses to large corporations. Significantly, among the reasons for expanded competition is the entrance of the banking industry into the remittance market.

Researchers associated with the World Bank would take up this type of research into the structure and characteristics of the remittances-transfer industry by the mid-20oos. From 2005 onward, the World Bank released a series of monographs presenting detailed research about the particular binational "remittances corridors" linking specific countries of origin and reception. In this body of research as well, competition became the central motif in explanations of the reduction of transfer costs, as in the following excerpt taken from the first of these monographs, which again addressed the U.S.-Mexico corridor:

In the past there was no real "market" for intermediaries in the U.S.-Mexico corridor. The role in the formal sector was dominated by MTOs [money-transfer operators], such as Western Union and MoneyGram. . . New competition from banks has brought about lower prices, faster services, and more reliable transactions. As a consequence, there is now a "paved road" for remittances between the United States and the urban and regional centers of Mexico.

(Hernández-Coss, 2005: 22) 
What these two excerpts demonstrate is that the research on the structure of the remittance-transfer industry identified competition-particularly from banking institutions-as the key to driving down the price of transfer services. The (apparently) successful entrance of banking institutions in the Mexican case was used to illustrate this dynamic and to provide an example to be replicated in other remittance corridors. This logic was made explicit in the foreword to HernándezCoss's work on the U.S.-Mexico corridor, where we read that this research intended not only to "underline some of the critical themes that identify the corridor" but also to highlight "the experiences that could serve other economies to transform their own remittances corridors into transparent and more competitive systems" (Waxman, 2005).

The research also aimed to demonstrate how banks and credit unions could be profitable in this competitive environment. Orozco, drawing from interviews he conducted with executives at banking institutions, suggested that banks and credit unions understood their interests as focused "not exclusively on transfers, but on establishing a long-term relationship with senders," which formed the basis for a strategy to "capitalize on money transfers as a way to increase their assets" (Orozco, 2004: 28). This research thus suggested that, even with significantly lowered transfer costs, banking institutions and credit unions could profit from migrant remittances, because these offered a means of capturing an "unbanked" sector of the population, bringing them and their savings into the institutions and eventually engaging them with other financial products and services, such as credit cards, auto loans, and mortgages.

All this research into the structure of the remittancestransfer industry was not simply left on the shelves but was 
actively disseminated by promoters of the R-2-D agenda. The MIF remittances program, for instance, endeavored to put the particular knowledge gained from this research into motion by releasing research reports to great fanfare at numerous public events promoting remittances as a development tool in Washington, D.C., and across the continent. A 2010 evaluation of the MIF remittances program documents that it organized at least fortyfive "conferences and roundtables in both remittance-sending and remittance-receiving countries, including events in the LAC region, North America, Asia, Africa and Europe" (Hall, 20Iо: 5).

Drawing on the commissioned research and its identification of increased competition as the key to transfer-cost reductions, MIF staffers also put this knowledge into circulation by directly advocating for the entry of banking institutions into the industry. An indication of this was provided to me during my interview with an MIF staffer who spoke about his early work in the program trying to educate banking institutions about why they should care about migrants and their remittance transfers. He described how, in these early days, they understood that their financial-education efforts would have to address not just migrants but also officials within banks and credit unions. When addressing the latter, they would show them demographic projections and explain that any institutions that wanted to maintain a position within the banking business in coming decades would have to "be in the Latino banking business." MIF officials marketed this as a tremendous opportunity for banking institutions, suggesting that offering remittance-transfer services promised much more than a onetime service fee; beyond that, these services could be used to attract a client base in need of a full range of financial products and services (Interview with MIF staffer, 2009). 
Similar direct-advocacy work with financial institutions, carried out by MIF staffers and those working in other development agencies, continued in later years. It has been particularly common for these advocates to make their pitches at the meetings of financial-services trade groups. For example, the IAD's Manuel Orozco, along with representatives from the U.S. Federal Reserve Bank, U.S. Bank, and Wells Fargo, participated in a session entitled "Remittances-Sizing the Revenue Opportunity in CrossBorder $\mathrm{P}_{2} \mathrm{P}$ " at the Banking Administration Institute's (BAI) 2008 "BAI Payments Live" conference, where they discussed strategies that banking institutions might employ to gain a foothold in the lucrative remittances market. These advocates have also regularly participated in the meetings of the National Money Transmitters Association (NMTA). As he spoke to the money-transfer operators assembled at the NMTA's 2008 convention, Gregory Watson of the MIF suggested that providing remittances services was "not just corporate social responsibility; it is a market opportunity for all of you." Then he argued that:

There has to be a business case and it has to be part of your business model to offer these types of products, to not look at a remittance client as just a client that you're taking the money from for the transaction, but that you're building a relationship with ... and that you have a strategy going forward to cross-sell other products. I know that that's what the successful banks that have been working in this sector have been doing and ... there's a lot of room for partnerships between MTOs and banks in this regard.

(Watson, 2008)

Just how entrenched these direct-advocacy efforts had become was made patently clear with the NMTA's decision to organize a 2010 meeting, entitled "IMTC Mexico 20I0, the 
International Money Transmitters Conference," in conjunction with the "RemesAméricas" conference organized by the InterAmerican Development Bank in Mexico City in May 20I0. This latter forum was advertised as "a platform that provides a space for dialogue and discussion where actors in the remittances market can exchange lessons learned and successful experiences with projects implemented over the last ro years in Latin America and the Caribbean." ${ }^{3}$ We will see more of these directadvocacy efforts in the case study of the Directo a México program in chapter 5 .

\section{THE DESIGN AND DIFFUSION OF BEST}

PRACTICES ON REMITTANCES

This work of conducting research into the remittance-transfer industry and identifying competition as the key factor driving down costs to consumers led to the second type of costreduction work carried out by the development agencies and their allies. This was to draw up recommendations for financial institutions, government officials, and civil society about "best practices" regarding regulatory issues, barriers to market entry, and the potential use of new technologies in the industry. The MIF drew up a set of such recommendations, which were presented at its 2004 regional conference in Lima, Peru (MIF, 2004: $3-4)$. These "basic" or "core" recommendations, later reproduced in many of the program's reports and promotional materials, were apparently written in collaboration with a broad set of remittances stakeholders. In unveiling these core recommendations, MIF manager Donald Terry described them as a set of best practices among the private sector and remittance-service 
providers, public authorities, and civil society that would assure a more efficient, transparent, and competitive market:

In order to help reach [its policy goals], the MIF, after consulting with an Advisory Committee of 22 organizations, is today issuing a set of Core Recommendations to Promote Best Practices in the Latin America and Caribbean Remittance Market:

REMITTANCE INSTITUTIONS-improve transparency; promote fair competition and pricing; apply appropriate technology; seek partnerships and alliances; expand financial services;

PUBLIC AUTHORITIES — do no harm; improve data; encourage financial intermediation; promote financial literacy;

CIVIL SOCIETY—leverage development impact; support social and financial inclusion.

(Terry, 2004: 4)

A report from an Inter-American Dialogue "Task Force on Remittances," also released in 2004, offered similar recommendations. That report outlined a series of agencies and interventions that could lead to transfer-cost reductions and an increase in the participation of remitters and recipients in the formal financial system. Again in this report, we find that the recommendations are targeted not just at state policymakers but at a wider swath of remittance stakeholders, including banks and other financial institutions, migrant associations, and nongovernmental organizations. In fact, one of the more striking features of the recommendations coming from these agencies is their antistatist nature. In the IAD task-force report, for example, governmental authorities are repeatedly enjoined to help facilitate the realization of the remittances-to-development objectives; these prescriptions, however, do not entail much in the way of proactive state action that could help accomplish the objectives. Instead, the recommendations offer up a litany of 
actions that states should not take, lest they interfere with the smooth functioning of market forces that promise to bring about an efficient and competitive industry. Thus, the report makes the following series of admonitions to public authorities: "Governments should not, for instance, limit the amounts or restrict the destination of remittances, nor should they seek to prescribe how remittances are sent or used. They should not set prices for remitting institutions, nor should they collect taxes on remittance transfers" (IAD, 2004: I4). The overall message is summarized a few short lines later, using language identical to that found in the MIF's core recommendations, where we are told that the report's "strongest recommendation to governments and international agencies is to follow the advice of Hippocrates to the medical profession-first, do no harm" (IAD, 2004: I4).

When the issue of remittances was addressed by Group of Eight (G8) leaders in 2004, fully incorporating remittances into the heart of official development discourse and practice, this led, among other things, to the formation of a working group on the "payment-system aspects" of remittances that would release another set of recommendations in 2007 (Bank of International Settlements and The World Bank, 2007). Here again, this report, written on behalf of a task force composed of representatives from central banks in both remittance-receiving and remittance-sending countries, as well as from the internationaldevelopment agencies, was based on the "belief that the best way to reduce the price of remittance services and make them more accessible is to encourage competition-in particular, to make the market for remittances more open and thus "contestable" (Bank of International Settlements and The World Bank, 2007: 2). From this belief, the G8 task force developed a set of five general principles designed to encourage transparent, efficient, and 
competitive markets, "sound, predictable, non-discriminatory and proportionate" legal and regulatory environments, and "appropriate" governance and risk-management practices (Bank of International Settlements and The World Bank, 2007: 4). While the report is careful in suggesting that these "general principles" are "not intended to be prescriptive but rather to give guidance" (Bank of International Settlements and The World Bank, 2007: I), nearly a quarter of the report is dedicated to developing a strategy for implementation of the general principles and detailing possible actions to ensure their realization.

Overall, the effect of these multiple iterations of best-practice recommendations by development agencies and researchers has been to construct, normalize, and diffuse a particular set of market-based solutions to the problem of high transfer costs, first developed for the Latin American region, across the entire globe.

PRICE-COMPARISON WEB SITES AND THE FORMATION OF KNOWLEDGEABLE CONSUMERS

The third type of governmental work carried out by development institutions and government agencies to lower transfer costs sought to make the costs of remittance-transfer services more transparent to consumers. In carrying out these activities these agencies and institutions demonstrated an apparent disbelief that the remittance-transfer companies themselves - that is, the market - would actually carry out the best-practice recommendations and "disclose in a fully transparent manner, complete information on total costs and transfer conditions, including all commissions and fees, foreign exchange rates applied, and execution time" (MIF, 2004: 3). But rather than pursue national 
or international regulation of this sector of the financial-services industry, officials within these organizations again focused their energies on a market-based solution.

The most common technique used to make the full cost of transfer services transparent to consumers has been the construction of databases and Web sites that provide detailed information about the cost and characteristics (e.g., delivery times, geographic coverage, etc.) of all available services. Such databases and Web sites promise to equip remitters with all the information necessary to make a rational calculation of the transfer provider that best meets their service needs and economic interests. The Mexican Consumer Affairs Agency (PROFECO_Procuraduría Federal del Consumidor) initiated this type of information gathering and diffusion in 1998 with its "Quién es Quién en el Envío de Dinero" campaign. ${ }^{4}$ This continuing project provides weekly reports on the fees charged to send $\$ 300$ to Mexico by the various service providers operating in nine major U.S. cities: Chicago, Dallas, Houston, Indianapolis, Los Angeles, Miami, New York, Sacramento, and San Jose.

The United Kingdom's Department for International Development (DFID) launched a similar initiative in 2005. DFID's "Sending Money Home?" project ran a Web site-later privatized-that "provides consumers with an independent comparison of the best value services offered by Banks, Money Transfer Operators (MTOs), FX [foreign-exchange] providers and prepaid cards for transferring money abroad taking into account their fees, real-time exchange rates, speed and method of transfer." The Send Money Home Web site would later expand beyond the UK transfer market to provide cost information about transfer services to and from nearly anywhere in the world. 
The World Bank also launched a price-comparison Web site, entitled "Remittance Prices Worldwide." The bank soon coronated itself as the leading authority on price-comparison databases and Web sites and even took on the role of certifying national databases. In a 2010 policy paper, the World Bank outlined twelve "mandatory requirements of a national remittance price database" (World Bank, 20Iо: 6). Under this policy, those national databases that met the minimum standards outlined were to be granted a World Bank seal of certification.

The foregoing examination of these different types of governmental work that went into the construction of a marketbased solution to the problem of high remittance-transfer costs demonstrates the significant role played by development institutions and public authorities in the construction of a competitive transfer market. As we have seen, the role that these agencies and organizations have played has largely eschewed the traditional role of a public authority that might be expected to implement and enforce legal and regulatory requirements. Such an option was, of course, always available, and it was at times contemplated. In the United States, for instance, representatives Luis Gutierrez and Barney Frank co-sponsored a bill in the ro8th Congressional Session (2003-4), the International Money Transfer Disclosure Act, that would have mandated price transparency-full disclosure of fees and exchange-rate spreads - but that option did not make it through the legislative arena. Similarly, in the United Kingdom, the 2005 report of the UK Remittance Working Group suggested that consideration should be given to "whether it is practical to recommend that it be a requirement for remittance providers to display a single figure showing total charges" (UK Remittance Working Group, 2005: 28). In the end, DFID opted 
not to implement a regulatory requirement. Instead, DFID drew up a voluntary "Remittance Customer Charter" that approximately half the transfer companies operating in the United Kingdom chose to adopt (Kansal, 2008). The major commitments that the companies accepted with this charter included providing migrant remitters, prior to initiating a transaction, with "an estimate" of the fees that they would be charged and "an indication" of the exchange rate to be applied to their transaction, if requested by the customer (UK Remittances Task Force, 2008). Even with this charter, then, it seems the transfer companies had still not committed to full transparency.

This rejection of mandatory rules and regulations illustrates how the governmental work of the development agencies and public authorities, rather than emphasizing the implementation and enforcement of legal requirements, was oriented toward the construction of a competitive, transparent, and efficient market for remittances services that, it was assumed, would meet the ultimate public-policy objective of lowering transfer prices. It is probably too early to tell whether the transparency offered by the proliferation of internet-based price databases, and the increase in competition within global transfer markets that such transparency may help to bring about, will contribute to significant price reductions over the long run. The results to date of these efforts at introducing greater price transparency have been impressive. Taking the Latin American region as a whole, the average cost to send $\$ 200$ from the United States dropped from 8.7 percent in November 200I (Orozco, 2003) to 7.27 percent by September zoro (Payment Systems Development Group, 20I0). In the U.S.-Mexico transfer corridor the average price dropped from 7.95 percent in November 2004 (Orozco, 2004) to 4.47 percent by the second quarter of $2014 .^{8}$ 
And while entry of new competitors into the market may be part of this story, it is also clear that some of these new entrants are attracted by the reigning price structure and the "frothy" profits that this price structure offers them. While we saw some of the larger banking institutions in the United States that entered the market in recent years offer their clients very lowcost or even no-cost transfer services (Wells Fargo's "ExpressSend" and Bank of America's "SafeSend" products are two prominent examples), such offerings have been far from the norm. For the most part, according to a December 20 Io analysis of the World Bank's global-price database, the transfer services offered by commercial banks continued to be the most costly on offer (Payment Systems Development Group, 20Io: 4). And recent developments suggest that many banks have shuttered their remittance-transfer windows altogether in response to limited consumer interest and/or perceived regulatory pressure to step up monitoring of cross-border money transfers. This has led some industry observers to suggest that the cost for transfer services may increase in the near future. (See Corkery, 20I4.)

Most important, significant reductions in the average price of available transfer services would not on their own lead to billions of extra dollars remaining in the pockets of migrant remitters and their friends and family back home. Rational, price-centric behavior by migrant remitters is the essential causal mechanism that would translate market transparency, increased competition, and lower average prices into cost savings for migrants themselves. Only if remitters were to favor those market players offering their transfer services at the lower end of the price structure could market competition lead to the developmental outcomes promised by this line of the R-2-D agenda. However, migrants remitting monies to family and friends back 
home may not act like automatons responding solely to price signals; convenience, familiarity, trust, and force of habit may be just as important as pricing when migrants make decisions among different transfer options. Migrants may someday come to resemble the ideal price-conscious consumer that they are assumed to be; but if migrants are going to act as good financial subjects, drawing upon a price-centric economic rationality to choose among the various remittance-transfer options available to them, they would need to be trained to think and act in this way. Such training is the objective of the financial-literacy campaigns analyzed later in this chapter and in chapter 5, below.

This reliance on financial-education and financial-training campaigns indicates the larger point: even if transparency and competition do eventually lead to significant price reductions and leave more money in the pockets of migrants and remittances recipients, this eventuality will not have resulted from the unleashing of market forces. The significant governmental work undertaken by development agencies and public authorities intent on constructing this particular type of market-based solution will be the underlying cause if the much-desired cost savings do indeed take hold.

\section{LEVERAGING REMITTANCES FOR DEVELOPMENT}

Beyond their efforts to reduce the cost of transfer services and leave more money in the pockets of migrant remitters and their family members, the proponents of the R-2-D agenda promoted means to leverage remittances for development by incorporating these monies within financial institutions and markets. As mentioned above in chapter $\mathrm{I}$, the question of the impact of migration and remittances on development processes in sending 
communities, regions, and nations has long been of interest to scholars. The debates on the remittances-to-development problematic that unfolded in the latter part of the twentieth century were usually framed in terms of the use of remittances and their impact on economic life in sending communities. The central question at issue was whether remittance monies were (or could be) employed in productive activities. A camp of so-called pessimistic scholars (Alarcón, 2002) argued that the vast majority of remittances were gobbled up by everyday expenditures and conspicuous consumption, and thus contributed little to the expansion of productive capacity in migrant-sending regions (e.g., Mines, 198r; Reichert, 198I). In contrast, a more "optimistic" camp argued that even this consumption brought positive impacts as these monies circulated through the wider economy and brought about "multiplier effects" that spurred productive activity (Durand, Parrado, and Massey, 1996; Taylor, 1999).

Given these earlier academic debates about the relationships between migration, remittances, and development, the remarkable thing about the recent political and discursive interventions of the development industry regarding remittances is not that remittances were finally discovered as a potential contributor to development processes in the global South. The most important effect of the development institutions' contemporary discourse on remittances-to-development has been to displace earlier discussions about the use of remittances and whether it is possible to channel significant proportions of these monies toward productive activity. In place of these earlier concerns, the contemporary discourse of remittances-to-development has centered attention not on migrants' own use of remittances but on the pathways of transmission of their monies. 
Building upon the representation of remittances as a financial flow, the recent interventions of the development institutions have had two principal effects. First, they have decentered the issue of the productive investment of remittances and effectively reframed the question of the development potential of remittances in terms of "financialization" (Erturk et al., 2007; Leyshon and Thrift, 2007; Langley, 2008). Second, in centering attention on the incorporation of remittances into financial markets, this discourse highlights the development potential of the products and services offered by banks and formal financial institutions and, consequently, devalues the alternative transfer options often employed by migrants, which range from the social-network-based services of Salvadoran viajeros (Mahler, 200I; Landolt, Autler, and Baires, 1999) or van operators in northern Mexico (Hernández León, 2008) to the formal-service providers, such as Western Union, that dominate much of the industry. In sum, these interventions have successfully rearticulated the nexus between migration, remittances, and development so that the issue on the agenda of the development industry is now mostly about how to leverage remittances for developmental purposes by incorporating the monies generated through cross-border migration into financial markets and formal banking institutions.

This leveraging of remittances for the purposes of financial development is envisioned in two principal ways: (I) by linking remittances to innovative financial instruments that could increase access to development finance in the countries of the global South; and (2) through the democratization of financial services whereby banks, credit unions, and microfinance institutions offer remittances-transfer services and begin to provide migrant remitters and remittance recipients expanded access to 
a broader swath of financial services, including savings, insurance, and credit products. In what follows I briefly examine the issue of remittance securitization before moving on to unpack the "financial democracy" element of the R-2-D agenda. In both cases I analyze the discursive and programmatic aspects of these interventions and highlight the governmental work employed in attempts to make reality conform to these discursive models.

\section{REMITTANCES AS AN INNOVATIVE SOURCE OF DEVELOPMENT FINANCE}

A broad debate materialized in the early 2000 s about potential new funding mechanisms - often characterized as "innovative sources" of development finance-that might help to reach the international-development targets contained within the Millennium Development Goals (MDGs). ${ }^{\text {T Th }}$ Thearch for new sources was necessitated because the traditional mainstay of development finance, the official development assistance (ODA) provided largely by the OECD member countries, was seen as falling short of the monies needed to meet these newest international commitments to development. The $200 \mathrm{I}$ report of the "High-Level Panel on Financing for Development"- often referred to as the Zedillo Report-prepared for the United Nations in advance of the International Conference on Financing for Development to be held in Monterrey, Mexico, in March 2002 estimated that an additional \$50 billion per annum would be needed to meet the MDGs. Reaching this funding threshold would require a doubling of then-current ODA levels (HighLevel Panel on Financing for Development, 200I: 20). Yet most observers believed that this ratcheting up of ODA funding was unlikely in the near term. Thus, the search for innovative 
sources of development finance was begun (Atkinson, 2004: 4-6; Ketkar and Ratha, 2009c: I).

Migrant remittances-now constituted as a financial flow, as we saw in the last chapter-have been a central component in these discussions of alternative sources of development financing. For instance, a study conducted by researchers associated with the United Nations University included "increased remittances by emigrants" as one of the seven innovative funding mechanisms examined, along with global carbon taxes and the "Tobin tax" proposal for taxing cross-border financial transactions (Atkinson, 2004; Solimano, 2004).

In most cases the integration of remittances into these discussions of innovative sources of development finance was understood in rather conventional ways. The only innovative features were that a previously overlooked financial flow was brought into discussions about development finance and a variety of mechanisms were identified through which "remittances can support economic growth in recipient countries" (Solimano, 2004: 177). The integration of remittances within discussions of development finance reached its zenith (or perhaps its nadir) with the publication of the 2002 report by the U.S. Agency for International Development (USAID) entitled "Foreign Aid in the National Interest." One chapter within that report, penned by Carol Adelman, a fellow at the Hudson Institute, identified migrant remittances as an integral part of the development assistance provided by the United States. Adelman argued that the "full measure" of U.S. foreign aid could be understood only by including private, nongovernmental sources of foreign assistance and development aid in addition to official government assistance (USAID, 2002: chapter 6; see also Adelman, 2003, 2009). This exercise was designed to counter the 
widespread portrayal of U.S. "stinginess" in regard to development assistance (USAID, 2002: 13I). Including private sources of development assistance, the scale of U.S. foreign aid more than doubles - jumping from $\$ 23.6$ billion in official U.S. government assistance in 2000 to over $\$ 52$ billion, according to the report's estimates (USAID, 2002: I3I).

The extraordinary aspect of this new, fuller image of U.S. development assistance is that the "private assistance" figures, while including the voluntary contributions made by corporations, foundations, and other private donors, are made up predominantly by migrant remittances-which, at $\$ \mathrm{I} 8$ billion in 2000 , constitute 55 percent of private assistance and 32 percent of total U.S. development assistance in this new definition. Two things are worth noting about this particular way of integrating migrant remittances into discussions about development finance. First is the brutal irony of positioning remittances as a fundamental component of development aid at the same time that the United States pursued increasingly harsh immigration and border-enforcement policies. The policy contradiction is stunning. While U.S. policymakers were dedicating increasing resources to curtail the flow of unauthorized migrants and thus make the trek across the U.S.-Mexico border much more treacherous (see, among others, Andreas, 200I; Cornelius, 200I; Nevins, 2002; Martínez et al., 20I4), the remittances sent home by those migrants who had successfully skirted these efforts at deterrence were presented as evidence of the foreign-aid "largesse" of the United States (Adelman, 2003). Second, the report illustrates that, despite repeated pronouncements by the champions of the R-2-D agenda that these monies should not be understood as a substitute for ODA (see Ratha, 2007: 8; Vargas Lundius et al., 2008: 7), in practice migrants' remittances have been used to 
justify limited expenditures on development assistance, at least within U.S. development-policy circles.

While it is difficult to find much that is really innovative about this incorporation of remittances into discussions of development finance, another set of scholars and policy entrepreneurs - mostly affiliated with the World Bank-were working on other ways to link migration and remittances to "innovative financing for development" (Ketkar and Ratha, 2009b). Authors such as Dilip Ratha, Suhas Ketkar, and their associates ${ }^{10}$ have analyzed and promoted a number of financing mechanisms related to migration and remittances that might "expand access to capital and lower borrowing costs" for developing countries and subsovereign and privatesector entities within them (World Bank, 2006: 86). In the view of Ketkar and Ratha, this need to expand access and cheapen the cost of capital for developing countries derives from changes in the structure of global finance in the wake of the global debt crisis of the $1980 \mathrm{os}$. According to the history they narrate, financing for developing countries in the period leading up to the r $980 \mathrm{~s}$ debt crisis came nearly exclusively from bank loans. As part of the resolution to the crisis brokered by the U.S. Treasury Department beginning in 1989 , much of the outstanding debt held by developing countries was then converted to bonds. And while this "switch from bank loans to bonds increased the availability of capital[,] in all likelihood it also increased the volatility of financial flows" (Ketkar and Ratha, 2009c: 5). Thus, in a period marked by a dearth of official development assistance and increasing reliance on capital markets for development finance, it is the volatility of capital flows to developing countries that explains the contemporary search for innovative sources of development finance; as these World Bank researchers say, "Little wonder that developing countries and financial markets have attempted to come up with 
innovations that provide access to funding during times of financial stress" (Ketkar and Ratha, 2009c: 6).

This conclusion may accurately describe the rationale for seeking out innovations in development finance given the current structure of global capital markets. But in identifying developing countries and financial markets as the agents behind this search for innovations, the authors minimize their own role, and that of the institution they are attached to, in constructing, promoting, and implementing these innovative mechanisms. In discussing the principal remittances-related financial innovation promoted by these scholars - the securitization of remittances as a future-flow receivable-I want to illustrate not just the structure and promised outcome of this innovative financial mechanism but also the governmental work engaged in by these policy experts as they sought to bring such a model into being.

Researchers with the World Bank have been analyzing and strongly promoting the use of remittances-backed securities over the last decade (Ketkar and Ratha, 200I, 2004-5, 2009a; World Bank, 2006; see also Terry, 2005: I4). How does this process of remittance securitization work? And how exactly would this leverage remittances for developmental purposes? Like the securitization of other "future-flow receivables" in the developing world, the design of securitized remittances transactions is aimed at generating an improved credit rating for a particular bond transaction by setting up an offshore "special purpose vehicle" through which future payments will be channeled before reaching the government or private-sector issuer of the securitized bond (Ketkar and Ratha, 2009a: 26-29).

Let me try to illustrate this innovative financing mechanism with a hypothetical example. A Mexican financial institution that 
processes a significant volume of remittance transfers, paying funds to recipients in Mexican pesos-let's call this hypothetical institution "Banco Jalisciense"-might attempt to leverage the remittance funds that flow through it by floating a securitized bond and pledging future remittances receipts for repayment. As part of this transaction, a special-purpose vehicle would be created in the United States. Other banks and financial institutions would be instructed to channel future remittance payments to be processed by Banco Jalisciense through this special-purpose vehicle. Before any future remittance funds ever reach Banco Jalisciense, the special-purpose vehicle would use the incoming remittance monies to pay off bond investors. Only after these payments to investors have been satisfied would excess funds then be forwarded on to Banco Jalisciense for distribution to remittance recipients.

The securitization structure promises significant benefits to bond investors in that "the government of the borrower cannot impede timely servicing of securitized bonds" (Ketkar and Ratha, 2009a: 27). As Gandy and Festa (200I) argue, the structure of future-flow receivable securitization is designed to mitigate the risk of "sovereign redirection," whereby a government facing a severe economic crisis

may attempt to interfere with or redirect hard currency cash flows.... To mitigate these risks, obligors sign acknowledgements agreeing to make payments into trust accounts maintained outside the emerging-market country. These acknowledgements are typically governed by New York law, thus requiring an emergingmarket government to convince a U.S. court to allow the redirection of these payments in violation of a security document, which is highly unlikely.

(Gandy and Festa, 20or: 92). 
These risk-mitigation features built into the securitization structure promise, in turn, to allow borrowers to access credit on more favorable terms, which in effect gives financial institutions and government agencies within developing countries the ability to "pierce the sovereign credit ceiling and obtain financing at lower interest costs and for longer duration" (Ketkar and Ratha, 2009a: 27). Improving a borrower's investment rating and providing access to credit on more favorable terms are thus the central benefits offered by the securitized transaction.

Such securitization schemes are seen as a promising tool for governments and firms in the global South to further leverage remittances (Ketkar and Ratha, 2009a: 39). Analysts of securitization repeatedly emphasize that there is significant potential for growth in this "asset class," which-if exploited-could greatly expand access to global capital markets (Gandy and Festa, 200I: 95-96; World Bank, 2006: I03; Ketkar and Ratha, 2009a: 36-39). For instance, World Bank researchers project that, by taking advantage of the opportunities for the securitization of remittances, "developing countries could potentially issue nearly $\$ 9$ billion and low-income countries could raise up to $\$ 3$ billion annually from international capital markets" (World Bank, 2006: I03).

In these discussions, this specific outcome-improving access to capital markets - comes to signify the ultimate goal of development. This seems far removed from the search for alternative sources of funding to meet the Millennial Development Goals (MDGs), the task that had apparently given rise to the exploration of "innovative sources of development finance" in the first place. But this result does give us an indication of the political meaning and implications of this World Bank-promoted investment vehicle and project. The objective here would seem to be 
as much about using remittances as a vehicle to further extend the reach of financial markets in the global South as it is about finding new mechanisms to channel monies toward any type of human-centered development.

In his pioneering analysis of efforts to channel remittances into securitization instruments, Luis Eduardo Guarnizo suggests that this type of financial innovation results in a situation wherein "migrants are unintentionally providing, through their monetary transfers, badly needed hard currency to complement and even subsidize some of the consequences of neoliberal reforms imposed by international financial agencies on developing countries" (Guarnizo, 2003: 688). He concludes that the use of migrants' monetary transfers to improve the creditworthiness of their highly indebted home governments is "a clear expression of the creative malleability of capitalism to accommodate to new circumstances to reproduce itself" (Guarnizo, 2003: 689). Such a reading of the meaning and import of these innovative new financial instruments represents "capitalism" as a coherent unity itself capable of enacting changes in the world that will reproduce the conditions for capital accumulation. In concluding this section I would like to offer a different reading.

Rather than viewing these recent innovations as an indication of the internal and inherent capacities of capitalism to continuously rework itself to meet its functional requirements, I want to emphasize the key role of development and economic expertise in conjuring up these innovative financial vehicles and promoting their application and extension across the world. This means highlighting the significant governmental work undertaken by the policy experts and entrepreneurs within institutions like the World Bank who have taken it upon themselves to analyze, promote, and implement these financial-market-driven 
mechanisms for channeling resources for development to the global South.

To begin, it is important to acknowledge all the work done by development-industry officials and their associates-analyzed in the previous chapter-that went into the construction of remittances as a stable, growing, and countercyclical financial flow. This particular construction of remittances as a financial flow lays the groundwork for the expansion of financial instruments and markets into this domain. In fact, we may say that these financial innovations are possible only because this portrayal has been widely circulated and has taken root, giving rise to the expectation that migrants' future remittances will provide a steady and reliable stream of debt-service payments. But the researchers within the World Bank have done more than this in their attempts to promote these financial innovations as a means to further leverage remittances for development. The analytic work these policy experts have carried out on the history, present utilization, and future potential of these innovative mechanisms has been directed toward the identification of "constraints that have held back the issuance of future-flow-backed transactions" (Ketkar and Ratha, 2009c: 8).

Finally, having brought these constraints out into the open, these authors and the institutions they work for identify publicpolicy options for overcoming the constraints and fully exploiting the potential of this market-based instrument. In these discussions they identify at least three ways that international financial institutions (IFIs) like the World Bank could help expand the use of this asset class. First, it is suggested that these institutions could "at the very least ... play a useful function of educating public sector bureaucrats and private sector managers in developing countries" on the benefits of future-flow 
securities transactions and how they can and should be structured (Ketkar and Ratha, 2009a: 5I). IFIs also have a role in encouraging countries to adopt an "appropriate legal infrastructure," mainly in terms of reforms to bankruptcy laws so as to recognize the "true-sale" of future asset flows, thereby granting these security instruments immunity from liquidation in any bankruptcy proceedings (Ketkar and Ratha, 2009a: 49-50). Finally, these institutions could "boost the growth of future-flow remittance securitization" in more direct ways as well, such as by providing "credit enhancements," "direct or indirect guarantees," or credit-default swaps that would work to provide a series of benefits to investors, which would likely expand their thirst for these investment vehicles (Ketkar and Ratha, 2009a: 50-5I).

I will further analyze the meaning of these different forms of governmental work that go into the construction of these remittances-related financial innovations in the conclusion to this chapter. But first let me move on to examine a final theme within the R-2-D agenda-leveraging remittances to promote the democratization of financial services.

\section{MIGRANTS, REMITTANCES, AND THE DEMOCRATIZATION OF FINANCE}

The goal and the promise of the theme of "financial democracy" within the R-2-D agenda is most clearly articulated in the MIF remittances-program cluster's materials promoting its model of "remittances as a development tool." In these documents, the aggregate volumes of remittances that the development agencies have painstakingly endeavored to document are represented as "financial flows in search of financial products" (Terry, 
2005: I4). This leads to the following description of the particular financial products that can serve to leverage remittances for development:

Over the past five years, remittances have undergone dramatic changes. Over the next five years, the system can be entirely transformed.

By the end of this decade, remittances to Latin America and the Caribbean can be moved from the current "cash to cash" system into the electronic or digital transfer system of "account to account." The technology is already available; what is needed are entrepreneurial business plans and appropriate regulations frameworks. The costs of sending money home will continue to fall. More people will be brought into the financial system and remittances will be leveraged by linking flows to local microfinance institutions, home mortgages, and even the securitization of bonds for on-lending to local small businesses.

(Terry, 2005: 14)

While the founding document of the MIF remittanceprogram cluster also proposed efforts to channel some portion of remittances toward productive activity, within a few short years the program had largely abandoned this objective to focus intensively on the issues of incorporating migrant remitters, their family unit, and their monies into the formal banking system as a way to unleash financial democracy. This would soon become the dominant and recurring portrayal of the remittances-policy objective being pursued by much of the international development industry, forming the core of the MIF remittance cluster's agenda (Terry, 2005: Io-I2; Orozco and Wilson, 2005: 385-89) and the work of allied organizations such as the IAD and the IFAD (IAD, 2004: 9-15; 2007: 9-13; Vargas Lundius et al., 2008: 42-47). The strategic logic of valorizing efforts to incorporate remittances within financial markets 
over attempts to encourage direct migrant investment in productive activity also prevails in much of the work on remittances coming out of the World Bank. For instance, Dilip Ratha, undoubtedly the World Bank's leading advocate of the R-2-D agenda, argues that "efforts to channel remittances to investment have met with little success" and suggests as an alternative that "encouraging remittances through banking channels can improve the development impact of remittances by encouraging more saving and enabling better matching of saving with investment opportunities" (Ratha, 2007: 8).

In the elaboration of the financial-democracy agenda, MIF officials have drawn connections to (and legitimacy from) the influential policy prescriptions of the Peruvian development economist Hernando de Soto (2000) and the U.S.-based management guru C. K. Prahalad (2004), who have, in their own distinct ways, argued that fully incorporating the poor within the dynamics of global capitalism, recognizing their value as both entrepreneurs and consumers, holds the key to the eradication of global poverty and inequality. The MIF discourse compares migrant remitters and their family members with de Soto's informal entrepreneurs - who are unable to free the "dead capital" locked within their untitled assets (de Soto, 2000)-and suggests that the former could potentially wield significant economic power, if only their unseen assets were recognized by financial markets and institutions. The discourse identifies the rationale for banks and other financial institutions to open up to migrants and remittance recipients, granting them access to formal financial services in that, echoing Prahalad (2004), these long-ignored potential customers represent a "fortune at the bottom of the pyramid." (See Terry, 2005: 8.) Drawing on these neoliberal mantras to present the case for financial democracy, 
the MIF program has thus articulated the $\mathrm{R}-2-\mathrm{D}$ agenda in a way that centers the logic of market transactions and incentives, rather than the guiding hand of state agencies or international authorities that might facilitate the connection between remittances and development. This is illustrated in the following excerpt from my interview with Donald Terry, where he contrasts his organization's emphasis on freedom, choice, and "more options" for consumers with the more heavy-handed conditionalities that the international financial institutions put on their loans in the recent past:

The real challenge here, and the real effort, is to leverage the development impact of those resources. For the first six months or so when we were realizing how big these flows were, I used the phrase that we should try to channel this money into more productive activities, and then I sort of slapped myself, realizing how f-ing arrogant I was. Because it's not our money; it's not like conditionality on loans that these international organizations make. So the mantra really is: You leverage the development impact by giving the people who send and the people who receive more options to use their money.... The challenge, as I put it now, is to turn the world's - because I'm now dealing with the world, and it's \$300 billion, it's not $\$ 75$ billion, you know. Can you take what is the world's most effective poverty alleviation program - and again, foreignaid people don't like to hear that, but that's too bad. Can you take the most effective poverty-alleviation program and turn it into the world's largest and most effective grassroots economicdevelopment program? I think it is an effective poverty-alleviation program. It is not-remittances is not an effective local economicdevelopment program, but it could be. And particularly it could be if you were to get the banking systems of both the sending and receiving sides better at this.

(Interview with Donald Terry, April 26, 2009) 
The effect of this discursive turn connecting remittances with financial democracy was to provide a way out of the impasse of the earlier scholarly debates - the question was no longer about the specific pernicious or beneficial economic effects brought about by remittances or about how to design public policies that could effectively channel a greater portion of these monies toward productive endeavors. In place of these earlier concerns, the purveyors of the R-2-D agenda posited a new model, whereby remittances could contribute to development if the logic of financial markets were extended to this as-yet untapped source of capital, if the monies of migrants and their family members were effectively leveraged within formal financial institutions.

It should be noted that, although often left unstated, the objective in leveraging remittances for development (much like the recent Mexican-state migration policies analyzed in chapter 4 ) is largely about stimulating economic activity in migrantsending regions as a means to diminish pressures for future outmigration. This was made explicit, for example, in the presentation that the IFAD remittance-program coordinator Pedro de Vasconcelos made at the 2008 International Money Remitters Convention.

De Vasconcelos used the graphic contained here in figure 3.I to explain to his audience that the efforts of the internationaldevelopment community to leverage remittances were designed to break a vicious cycle of migration-remittances-dependency:

[This is] the main idea from the development community that is interesting to understand. There is a circular phenomenon where if you send the remittances, they're sent, they're received, consumed, therefore you create some need and they are a circular phenomenon. If you can leverage remittances at some point, when they are 


\section{Leveraging Rural Remittances}

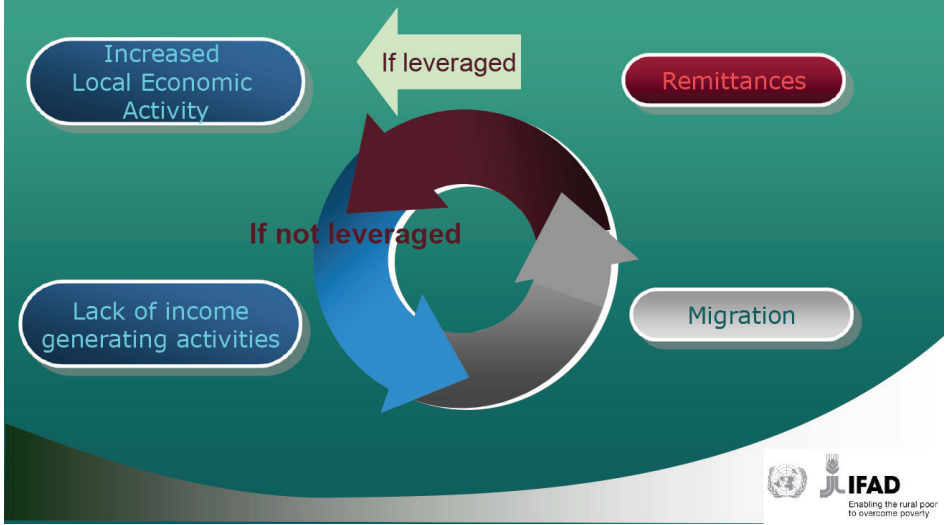

Fig. 3.I. IFAD graphic showing the potential effects of leveraging remittances. (Source: de Vasconcelos, 2008: 12.)

received, by giving them, by giving those who are using them more options-more options is more margins to use the money, basically, use their cash. More options to invest their cash. More options is also the way they receive it, just through a money transfer company, or they can receive it in financial institutions. These are the more options. That leverage effect can be enhanced by actually using, for instance, small businesses in rural areas. When you do that, you create local economic activity and at the end you expect to have a lesser need to migrate. So this is basically the philosophy behind it.

(de Vasconcelos, 2008).

But how, exactly, is this conquest of financial democracy, this particular means of leveraging remittances flows, supposed to materialize? As we have seen, the neoliberal rationality of the MIF centers the logic of the market as the driving force behind 
the transformations it envisions. For Terry (2005) the central factors driving financial democracy would appear to be the incorporation of new communications technologies, the creative energies of entrepreneurs, and the facilitating role of an "appropriate" regulatory environment. Elaborating the model of the agencies behind the leveraging of remittance flows in this way serves to displace attention from the governmental work required of the development agencies, and the partners they may be able to enlist in service of their project, to bring this vision of financial democracy into being.

This is, of course, necessary if the promoters of the R-2-D agenda are to distance themselves from the tainted history of disastrous interventions by the international financial institutions during the era of structural-adjustment programs, as we saw in Terry's denunciations above of earlier efforts by officials within international organizations-himself included-to direct the actions of their target populations, be they debtstrapped governments or transnational migrants. In place of such policy mandates, the champions of financial democracy celebrate the exercise of individual freedom, migrants' choice in the financial marketplace. But, of course, achieving this would also require the significant deployment of governmental power by officials within the MIF and allied organizations, because the forces and incentives of the market have not yet been enough to make their utopian vision of financial democracy into a reality.

While at the rhetorical level R-2-D policy entrepreneurs minimize the work that would be required to recruit banking institutions to provide transfer services and convince these and other financial institutions to create and market new remittancerelated financial products, ${ }^{\text {II }}$ the actual process of constructing financial democracy in the here and now-making reality 
conform to this discursive representation-involved significant governmental work to enlist government agencies and financial institutions as partners in the project of incorporating remittances within financial markets.

The portfolio of projects funded and implemented by the MIF remittances cluster provides a concrete illustration of the types of governmental work that went into the construction of financial democracy and "more options" for migrant remitters and remittance recipients. The cluster's projects have addressed remittances in a variety of ways, including the efforts to improve data collection and reduce transfer costs analyzed above, and, in early years, even to promote migrant investment in productive projects (Hall, 2oro). But without a doubt, the cluster has been most active in promoting projects aimed at leveraging the developmental potential of remittances through their incorporation within formal financial institutions, including banking institutions, insurance companies, and specialized housing-finance companies. These projects recruited banks, credit unions, and microfinance institutions to provide remittance-transfer services; they encouraged financial institutions to create new remittance-based financial products and "cross-sell" these to remitters and recipients; and they helped fund financial-education campaigns designed to form migrants and members of their transnational households into appropriate financial subjects capable of and interested in utilizing these new financial products and services.

The MIF program's portfolio included a variety of "banking the unbanked" projects across the continent that encouraged banks and other financial institutions to provide remittance-transfer services and create and cross-sell other financial products and services to their remittances clients. A project in the Dominican Republic, carried out in collaboration with a microfinance institution 
specializing in providing credit to women (Banco ADOPEM), for example, sought to establish relationships with international remittance-transfer companies that would allow the bank to operate as a receiver and distributor of remittances. Beyond this, the project aimed at the development of new "remittance-linked financial products," including life and accident insurance as well as a variety of "scheduled savings plans" to pay for education costs or a family vacation. (See Hall, 2010: 75-79; MIF-IFAD, 2005.)

Another project, this one carried out with the nongovernmental organization (NGO) Apoyo Integral in El Salvador, also endeavored to create new remittances-based financial products. The "transnational credits" designed through this grant project were offered for a range of purposes, including land or home purchases, home improvements, and small-business formation. (See Hall, 20I0: 7I-74.) An even more ambitious project with the Mexican government's second-tier development bank/ credit union Banco del Ahorro Nacional y Servicios Financieros (BANSEFI) aimed at creating the technological infrastructure that would allow over fourteen hundred affiliated institutions to receive and pay out remittances in both rural and urban areas across the country. This project also contemplated creating a variety of new financial products, such as debit cards, credit cards, and housing-savings plans, that could be used to recruit "remittance recipients as clients" (Hall, 20I0: 8I). The MIF program's emphasis on developing these new financial products was due in no small measure to the fact that, for the relatively small financial institutions that often partnered with MIF on the projects, making remittance transfers is "not inherently profitable (unless scalable to a great degree) and entities must rely on cross-selling other products and/or lowering the cost of the remittance service to achieve benefits" (Hall, 20Io: I48). 
Another common type of project within the MIF portfolio attempted to channel remittance monies into housing markets across the continent. Projects carried out in Colombia, El Salvador, Ecuador, and Mexico worked toward the design and marketing of transnational mortgage products to fund the purchase of houses in migrants' countries of origin. A common challenge faced in each of these projects was to find an appropriate means to spread the word among remittance senders about the availability of these new transnational mortgage products. Promotional materials were often distributed through consulates abroad. In the Salvadoran case, this strategy proved unsuccessful, because, according to Hall (2010: 32), "the majority of the people who visit the consulates are undocumented, and therefore not a target clientele for the mortgage product." The MIF-funded project in Colombia appears to have come up with the most ambitious marketing plan for the remittancesbased mortgage product, as the implementing agency designed a national database including the names of remittance recipients to be used in marketing their newly designed financial products. (See Hall, 2oro: I6.) In addition to its use in marketing the new transnational mortgage product, the information gathered for the database of remittance senders and receivers was to be used to create a credit-scoring model that would include remittances receipts. A similar attempt to create and refine new credit-scoring models to assess the creditworthiness of potential mortgage holders was also contemplated in a project with the Ecuadorian financial institution Mutualista Pichincha S.A. (Hall, 2oro: 34-38).

It is worth noting that many of the institutions involved in these banking-the-unbanked projects with the MIF decided to cancel or suspend their new remittances-related financial 
products as a result of the global financial crisis unleashed in late 2007. This decision was directly related to the particular characteristics usually attributed to remittances when constructed as a financial flow-their nature as "countercyclical flows." The promise of $\mathrm{R}-2-\mathrm{D}$ was predicated on this characterization: financial institutions recognized transfers as largely unprofitable, but offering transfer services might make sense if financial institutions could link remittances to new and innovative remittances-related financial products and services. However, the profitability of these remittance-related financial products could be realized only if remittances were indeed a stable financial flow. In the aftermath of the global financial crisis, many of the financial institutions that were recruited into the policies flowing from the R-2-D agenda have come to see that these financial flows were susceptible to the turbulence and instability of the global political economy. For these institutions, it would seem that their clients may not have conformed to the MIF's representation-noted in the previous chapter (see Meins, quoted in Migrant Remittances, 2008: 9) — that the resilience and adaptability of migrants, their willingness and ability to take on new jobs and work longer hours, would ensure a continuing flow of remittances.

The financial-education component of the MIF program's financial-democracy agenda is aimed, in essence, at reducing the divide between the discursive representation of migrant remitters and their households as entrepreneurial subjects and the actual financial and economic practices of migrants and remittance recipients. The discourse animating the financialdemocracy project represents migrants and their family units as "profoundly entrepreneurial" (Terry, 2005: 7), as rational actors who have set upon the path of cross-border mobility in 
no small measure because they lack access to credit and investment financing at home. The challenge of financial democracy is depicted as one of overcoming the exclusionary attitudes and practices of banking institutions in both the United States and the LAC region. This representation of the problem they faced was a common theme in my interviews with MIF program officials, who repeatedly condemned the past practices of LAC banking institutions that explicitly defined their clientele in classist terms. One MIF official, for example, suggested that "cultural problems" in some countries led bankers to exclude working-class people "in their sombreros," believing that their banks were only for "people in suits who work in Telefónica" (Interview with MIF staffer, 2009).

If the problem facing the promoters of the financialdemocracy agenda were only about migrants and remittance recipients being excluded from banking services, then successful work in convincing banks to open up access and provide new remittances-related financial products would be enough to unleash the far-reaching benefits they envisioned. But despite this rhetorical emphasis on the exclusionary practices and attitudes of banking institutions, the financialdemocracy effort could never be limited solely to the work of convincing banks to open up to migrants and their family members; it must also attend to the ideas, practices, and identities of the migrants and remittances recipients at the center of the project.

In 2009, reflecting the limited success of this financialdemocracy project, an MIF program document suggested the need for a restatement of the program's strategic orientation. Accordingly, the program would now place front and center the issues of financial inclusion and banking the unbanked: 
To continue moving towards the objective of financial inclusion, MIF has taken on the task of reformulating its strategy, orienting it more clearly towards projects that allow for a clearer diagnosis of the problems facing the region in terms of financial inclusion and on the role that remittances can play in terms of improving access to financial services by the underserved segments of the population.

(Analistas Financieras Internacionales, 2009: 18)

While this statement represents increased attention to the barriers to financial inclusion as a reformulation of the program's strategy, it is probably more accurate to say that the alreadyexistent financial-education or financial-literacy components of the decade-old strategy began to take on greater significance and become the program's strategic priority. This is to say that, despite rhetorical moves to represent migrants and their households as already-existing entrepreneurial subjects, a significant component of the R-2-D agenda has addressed the need to engage directly with the process of forming migrants and remittance recipients into good financial subjects. An important part of the MIF program's work, and that of many other allied organizations (see, for example, IAD, 2004; Appleseed México, 20Io), has thus involved financial-literacy or financial-education campaigns. The 2010 external evaluation of the MIF program notes that eleven of its funded projects were at least partly focused on financial education (Hall, 2010: 203). These efforts have been directed, according to Orozco and Wilson (2005:380), at the task of "creating new incentives - and the capacities needed for people to respond to these incentives - [in order to] make important changes in the way people think about and handle their money." Building these capacities for migrants and remittance recipients to respond rationally to the new financial products on offer is necessary work because "many migrants and their families lack 
financial literacy and thus are impeded in their ability to take advantage of new products and services" (Orozco and Wilson, 2005:385).

The MIF representative Gregory Watson sounded a similar note in his presentation at the 2008 National Money Transmitters Association meetings. Noting the central role that the MIF and other development institutions could play in helping to mold migrants and their family members into new financial subjects, Watson told the financial-services-industry representatives gathered at the conference that "you need to create demand for those [cross-selling] products and the way that you do that is by having the people involved in the transaction understand the benefits to them of those products. And that is a role that international institutions such as the IDB and others need to take seriously - which is to help build demand for these services" (Watson, 2008).

The financial-education component of the development industry's work thus often assumes that the failure of migrants and their family members to utilize financial services is a consequence of their ignorance of the products and services on offer from formal financial institutions. It is for this reason that they need to be educated about the benefits of formal financial services. This assumption tends to ignore another potentially relevant factor that could explain the limited use of the products and services of formal financial institutions, namely a mistrust in these financial institutions bred from personal experiences and the historical memory of financial crises, asset freezes, and bank/credit-union collapses across the continent. (See Bair, 2005: II8; Fagen and Bump, 2005: 234; Hernández-Coss, 2005; Paulson et al., 2006.) In addition, as pointed out by Paulson et al. (2006), when analyzing the financial services available to migrant remitters, cost comparisons do not always favor banks over check 
cashers and other informal financial services. This is because migrants, who like other people in low-income communities tend to experience fluctuating incomes and often live from paycheck to paycheck, can be left vulnerable to high fees and penalties for account overdrafts. These fees and penalties often make the financial services provided by banking institutions even more costly than those of the so-called alternative financial-services providers (Paulson et al., 2006: 20). For these reasons, we may reasonably believe that the problem facing the advocates of financial democracy is not simply the exclusionary practices of banking institutions, nor either the ignorance of migrants and their family members of the products and services on offer by those institutions. It may be that the phenomenon of financial exclusion is just as much the consequence of migrants' and remittances recipients' well-justified self-exclusion from these institutions.

To sum up, this section has examined the significant governmental work required to bring to life the vision of financial democracy. MIF officials and their allies recognized that financial institutions did not and would not open up to poor migrants and their family units solely as a response to market signals. Nor for that matter would migrants automatically flock to these institutions even if they were to become more welcoming of remittances costumers. Thus, those promoting this financialdemocracy project engaged in a coordinated effort to entice financial institutions at both ends of migrants' transnational networks to join their project. These efforts included: (I) recruiting financial institutions to provide remittance-transfer services; (2) funding projects with financial institutions and NGO partners to create innovative financial products and services that could be cross-sold to migrants and remittance recipients; and (3) funding and promoting a variety of campaigns to educate migrants and their family members about financial institutions, products, and 
services, and about their utility. In fact, if market signals had any significant impact in terms of the project of financial democracy, this appears to have come as a result of the global financial crisis, which actually drove many of MIF's partners to suspend their remittances-related financial products because of the instability of remittance flows.

\section{CONCLUSION}

In this chapter I have documented and analyzed three facets of the R-2-D agenda. The policies and practices contained within each of these facets of the broader agenda link remittances to development in different ways. This should really come as no surprise. Development is a positively charged "empty signifier" that can take on a wide variety of meanings (Ziai, 2009). In our case, the different facets of the R-2-D agenda posit a direct connection to the much-vaunted development by means of (I) reducing remittance-transfer costs and leaving a few extra dollars in the pockets of migrants, and (2) integrating migrants and their monies within formal financial institutions that will provide them access to financial products and services from which they were previously excluded, and (3) by incorporating aggregate remittance flows within financial markets via securitization, which will help generate a new source of development finance for governments and subsovereign entities in the global South.

As components of a broader neoliberal agenda, the different policies and practices of these three facets share important features. Most important, all three lines of the R-2-D agenda being pursued by the international financial institutions and their partners promote market-based solutions that will help remedy 
the problems they have identified, namely high transfer costs, financial exclusion, and the shortfall in development financing. However, as the preceding analysis demonstrates, what progress has been made in addressing these problems has not been driven by market forces. Rather, the construction and implementation of these market-based solutions has relied heavily on the significant governmental work undertaken by actors within the international institutions and by their partners in national governments, NGOs, and private-sector firms.

My intention in highlighting the governmental work done to bring about these market-based solutions is twofold. First, I am aiming to demonstrate the wide gulf between the ideology of market fundamentalism and the reality of neoliberalism in practice. The purveyors of this agenda may wish to portray the market as the preferred mechanism for resolving the socioeconomic and political problems that they have identified. But these governmental agents cannot sit back idly waiting for market forces to do their magic; instead, they actively intervene in an effort to bring about the market-based solutions that they envision.

Second, I hope that this analysis will provide a counter to accounts of contemporary political-economic transformation that center agency in the abstract logic of capitalism itself, or that portray governmentality as an anonymous, if not agencyless, mode of power. As I have demonstrated, we can identify the specific agents, institutions, and interventions aimed at putting into operation the governmental power that would help transform existing reality and bring about market-based solutions to the problems of migration and (under)development.

In many ways the materials examined in this chapter suggest that the particular neoliberal project pursued and diffused by these governmental agents works to depoliticize the issues of 
migration, remittances, and development - at least at the level of public-policy debates. ${ }^{12}$ These efforts at depoliticization can be seen in a review of research on the connection between migration and development penned by two World Bank researchers. That article begins with the assertion that "the central question about migration is not whether there should be more or less of it, but which policy options, adapted to their varying circumstances, countries have to increase the development impact of migration and remittances on their economies" (Page and Plaza, 2006: 318). This exemplar of the types of interventions in policy debate undertaken by the purveyors of the R-2-D agenda demonstrates their efforts to reduce the space for political debate and discussion, centering attention on public policies that governments of the global South can adopt to leverage remittances for developmental purposes. This and similar attempts to limit the issues up for debate displace attention from the migrationrelated policies of governments in the global North and, thus, studiously ignore both the barriers to lawful entry faced by migrants from the global South as they venture to the North and the unenviable experience of those migrants who risk the trek across increasingly militarized borders and, if they are successful, often endure long periods of dislocation from families and communities of origin.

In this sense, the R-2-D agenda may have depoliticizing effects (or intentions) on the imagining and discussion of political alternatives. It is worth questioning, however, just how effective the R-2-D agenda has been in reshaping reality to fit its policy models and objectives. The extent to which the discourse and practice of the R-2-D agenda have been successful at engaging migrants and their family members as "governable subjects" (Ghertner, 20Io) who see themselves and act in the ways they 
are expected to is one of the central questions addressed in the book's next part. In this excavation of Mexican-state migration policy and recent collaboration between government agencies and financial-services firms in the United States and Mexico we see the origins, content, and consequences of the R-2-D agenda on the ground in North America. 